\title{
A FOGYATÉKOSSÁGGAL ÉLŐ HALLGATÓK HELYZETE A HAZAI ÉS NÉHÁNY KÜLFÖLDI ORSZÁG FELSŐOKTATÁSI INTÉZMÉNYEIBEN
}

\author{
KOVÁCS KRISZTINA
}

az Eötvös Loránd Tudományegyetem

fogyatékosügyi koordinátora

kkovacs@barczi.hu

\begin{abstract}
A tanulmány egy sajátos helyzetben lévö kisebbségi csoport, a fogyatékossággal élö, felsőoktatási intézményekben tanuló fiatalok helyzetét elemzi a hazai, az amerikai és néhány európai ország gyakorlatának összehasonlitásával. Az irás ismerteti a hetvenes évektöl kezdödöen egyre nagyobb számban megjelenö publikációk szemléletbeli alakulását; a fogyatékos hallgatók létszámának változását; a különbözö országokban alkalmazott definíciók különbségeit. Tisztázásra kerül a hazánkban még ritkán használt „,ésszerü alkalmazkodás" fogalma. A szerzö legfontosabbnak a fogyatékos hallgatók számára nyújtott szolgáltatások minöségét és az egyenlö esélyü hozzáférés eszméjének megvalósulását tartja. A tanulmány rávilágít a hazai szabályozás pozitiv elemire éppúgy, mint a közoktatás és a felsöoktatás törvényi hátterében meglévö ellentmondásokra is.
\end{abstract}

\section{A fogyatékossággal élő fiatalok a felsőoktatásban - történeti áttekintés}

A fogyatékossággal élő fiatalok számára a továbbtanulás nem pusztán az egyéni érdeklődés kielégítését szolgálja, hanem sok esetben a munkavállalási esélyeik növelését is, mivel a funkcióbeli korlátok miatt a fizikai munkavégzéshez vezető szakképzés sok esetben nem jelent reális pályaorientációt számukra.

1864-ben, a Kongresszus jóváhagyásával az Amerikai Egyesült Államok elnöke, Abraham Lincoln törvénybe iktatta egy speciális főiskolai részleg megalapítását a Siketnémák Columbiai Intézetében, amelynek 1866-ban már 25 siket hallgatója volt. Ebből a tagozatból fejlődött ki 1986-ra az első tanár, Edward Miner Gallaudet édesapja után elnevezett önálló egyetem, amely, mint Gallaudet Egyetem, a mai napig is fogad siket diákokat (Madaus, 2011). E szegregált föiskola mellett a többségi egyetemeken is tanult egy-egy fogyatékos diák a XIX. század végén, a XX. század elején az USA-ban. Ilyen híres egyetemista volt például Helen Keller (1880-1968), aki siket-vaksága ellenére a Radcliffe Föiskola hallgatója volt 1900 és 1904 között, és summa cum laude minősítéssel szerzett diplomát (Kleege, 2006). Randolph Bourne (1886-1918), a tuberkolózis miatt súlyos háti gerinc deformitásban szen- 
vedő irodalomkritikus és esszéista, 1909-ben nyert felvételt a Columbia Egyetemre (Finger, 2006).

A mai napig leghíresebb veleszületetten vak orvos, Jacob Bolotin (1888-1924), aki 1908-ban iratkozott be a Valparaiso Egyetem Orvosi Karára, később szív- és tüdő specialistaként dolgozott (Perlman, 2008).

A fogyatékossággal élő egyetemisták nagyobb számban a II. világháború után jelentek meg az USA felsőoktatási intézményeiben, ugyanis a Kongresszus 1944-ben elfogadta a katonák újrakezdési támogatásáról szóló Serviceman's Readjustment Act nevü törvényt. Ez a törvény több kedvezmény között leginkább az oktatást kívánta elöremozdítani a katonai szolgálatot elhagyó amerikaiak körében. Hatására több mint két millió veterán került be az USA különböző egyetemeire az 50-es évek elejére és a föiskolák hallgatóinak 50 százalékát a volt katonák képezték ${ }^{1}$.

A veterán katonák egyetemre történő bekerülésének természetes velejárója volt a háborúban megsérült, rokkant fiatalok továbbtanulásának felvirágzása is. Az Amerikai Oktatási Hivatal egy 1950-es felmérésének megállapítása szerint: „Az amerikai felsőoktatás történetében elöször jelentek meg tömegével fogyatékos veteránok, fogyatékosság szerint az enyhébb sérültektől a súlyos testi fogyatékosokig. Ezek a veteránok, csakúgy, mint más fogyatékos hallgatók, sok tekintetben különleges szolgáltatásokat igényelnek, amely lehetővé teszi számukra a tanulmányi munkában történő elörehaladást" (Strom, 1950, 38. id. Madaus, 2011, 6. o.). Storm a tanulmányában javaslatokat is megfogalmaz arra nézve, hogy melyek legyenek ezek a speciális szolgáltatások, például: látó vezetők vak hallgatóknak, rámpák elhelyezése mozgáskorlátozott diákoknak, vagy jegyzetelők alkalmazása siket tanulóknak. Ebben az időszakban azokra az egyetemekre jelentkeztek föleg fogyatékos hallgatók, amelyek a veterán katonai kórházak és rehabilitációs központok közelében helyezkedtek el és a szolgáltatásokat nem az egyetemek, hanem a kórházak biztosították. Negatív diszkrimináció még gyakran volt tapasztalható, elsősorban a súlyosabban fogyatékos hallgatókkal szemben, föleg azokban az esetekben, amikor az egyetem közelében nem volt veterán kórház. A szakirodalom több esetet is leír, amikor az egyetemek elutasították a fogyatékos hallgatók jelentkezését (Madaus, 2011).

A felsőoktatásban tanuló fogyatékos hallgatók problematikájával az amerikai szakirodalom már az ötvenes évektől kezd foglalkozni. A polgárjogi mozgalmak és az új oktatási törvények megjelenéséig, vagyis a hatvanas évek elejéig érvényesül az a polémia, hogy vajon egy-egy szakon tanulhat-e egyáltalán fogyatékos diák. Az önrendelkező élet mozgalom leghíresebb alakja, Ed Roberts és súlyosan mozgáskorlátozott társai például nem kis harcok árán nyertek felvételt a Berkely Egyetemre 1962-ben (Leon, 2006).

A fogyatékos fiatalokkal kapcsolatos publikációk kezdetben föleg egy-egy eset ismertetéséről tudósítottak, melyekben mind a diák, mind az őt oktató tanárok

\footnotetext{
${ }^{1} \mathrm{http}: / /$ www.ourdocuments.gov/doc.php?flash $=$ true $\&$ doc $=76$
} 
problémájának feltárására és a pozitív megoldási minták közvetítésére teszik a hangsúlyt. A viták arra keresik a választ, hogy bizonyos szakok, mint például vegyész vagy biológus gyakorlati képzésében hogyan tud egy-egy fogyatékossággal élő hallgató részt venni. Az 1973-as Rehabilitációs Törvény megjelenése, különös tekintettel annak 504. paragrafusára, amely a felsőoktatással foglalkozik, nagy hatással volt a sérült hallgatók érdekérvényesítésének fejlődésére. A törvény kötelezte a felsőoktatási intézményeket, hogy a fogyatékos hallgatók fogadására készüljenek fel és biztosítsák a szükséges módosításokat és eszközöket. A szakirodalom figyelme is egyre inkább a problémára irányult és nagy számban kezdenek az e témával foglalkozó publikációk megszületni.

Stilwell és munkatársai a Kentucky államban lévő 57 felsőoktatási intézmény akadálymentesítésének állapotát vizsgálták. A megkérdezett intézmények közül 45 válaszolt. Ezen egyetemek 87 százaléka nem tartotta kizáró ténynek a felvételiző diák sérülését, ugyanakkor 50 százalékuk nem rendelkezett az írásbeli felvételi vizsga módosításának lehetőségéről. Az intézmények többsége az épületek akadálymentesítését elvégezte, a sérült hallgatók számára diáktanácsadóval rendelkezett és 60 százalékuk megszervezte a látássérült diákok személyi segítő szolgálatát. A szerzők hangsúlyozták, hogy mennyire fontos lenne sérült személyeket foglalkoztatni az egyetemeken (Stilwell et al., 1983).

Wilkinson egy rövid egyetemi tájékoztató füzetben ajánlásokat tesz a New York Állami Egyetem oktatóinak a sérült hallgatók megsegítésére. Az alábbi módosításokat javasolja: a vizsgákon a felkészülési idő meghosszabbítása; nagyobb rugalmasság a választható tárgyak felvételében; alternatív oktatási módszerek és speciális eszközök biztosítása; a tananyag hangkazettán történő tárolása és egy sérült hallgatókat segítő testület létrehozása (Wilkinson, 1981).

Az első nagyszabású tanulmányt az amerikai föiskolákon tanuló fogyatékos diákok helyzetéről Lawrence és munkatársai készítették 1981-ben. Több mint 5000 olyan sérült hallgató adatait dolgozták fel, akiket 1978-ban vettek fel az USA különbözö föiskoláira. A tanulmány vizsgálja a hallgatók demográfiai mutatóit a nemek, a sérülési típusok, a családi állapot, a középiskolai tanulmányi eredmények, a föiskola kiválasztásának szempontjai, valamint a hallgatók elvárásait, attitüdjeit és értékeiket. Az eredmények közül érdekesnek találom, hogy a fiúk aránya kissé magasabb volt a lányokénál; a sérült hallgatók mind szociokulturálisan, mind gazdaságilag hátrányosabb helyzetủ csoportot képeztek a nem sérült hallgatókkal való összehasonlításban; ugyanakkor elvárásaik magasabb értéket mutattak, a tanuláshoz való attitüdjük sokkal pozitívabb volt és több tradicionális akadémiai tárgyat választottak, mint ép társaik (Lawrence et al., 1981).

A nyolcvanas évek közepétől egyre több kutatás foglalkozik a sérült diákok felvételi vizsgán elért teljesítményeinek elemzésével. Bennett két központi felvételi teszt (ACT, Assessment Test és Scholastic Aptitude Test) eredményeinek adatait vizsgálta négy fő fogyatékossági csoportban, a hallássérültek, a mozgássérültek, 
a látássérültek és a tanulási zavarban szenvedők körében. A szerző megállapította, hogy a sérült felvételizők átlagban alacsonyabb pontszámot értek el, mint ép társaik. A négy alcsoport összehasonlításából kiderült, hogy a látás- és mozgássérült diákok közelítették meg leginkább a nem sérült diákok felvételi eredményeinek átlagát. Náluk alacsonyabb teljesítményt nyújtottak a tanulási zavart mutató és a hallássérült felvételizők (Bennett et al., 1984). Hasonló eredményekről számolt be Willingham, amikor 1539 fogyatékos diák érettségi vizsgán és felvételi vizsgán elért teljesítményeit hasonlította össze. Szignifikánsan alacsonyabbak a középiskolai eredmények a felvételin elért pontszámoknál. A szerző összehasonlította a sérült hallgatók felvételi eredményeit az ép diákokéval és ugyanaz a rangsor alakult ki, mint az előző két ismertetett vizsgálatban, vagyis a látássérült és a mozgássérült diákok az átlagot megközelítik, míg nagy elmaradást mutatnak a tanulási zavarban szenvedő és hallássérült felvételizők. Egy érdekes ellentmondásra is felhívta a figyelmet a szerző. Az egyetemek szívesebben fogadnának hallássérült diákot, mint tanulási zavart mutatót, $\mathrm{s}$ a látássérült és a mozgássérült diákokkal szembeni attitüdjük a legnegatívabb (Willingham, 1987).

Nagy áttörést jelentett az USA-ban az 1990-ben megjelent, a fogyatékos személyek esélyegyenlőségét biztosító törvény (Americans with Disability Act, ADA). A törvényben szereplő kifejezés, az ún. „reasonable accomodations”, vagy ésszerü alkalmazkodás azt a szemléletet tükrözi, hogy nem a fogyatékos személynek kell alkalmazkodnia a különböző akadályokkal teli környezethez, hanem a többségi szolgáltatásokat kell úgy átalakítani, hogy azokat fogyatékossággal élő személyek is használhassák. Ez a kötelezettség az egyetemekre is vonatkozik, amennyiben a módosítások végrehajtása nem okoz aránytalanul nagy terhet az intézmény számára. Az ADA hatására megnövekedett fogyatékos hallgatói létszám paradigmaváltásra késztette a felsőoktatást, $\mathrm{s}$ ez szembetünően megváltoztatta e korszak publikációinak a hangsúlyát. Nem az eddig jellemző problémák (a felvételi eredmények elemzése, vagy a sérült hallgatók teljesítményeinek rangsorolása) kerülnek a közlések fókuszába, hanem a már megalakult és müködő, a sérült diákokat segítő szolgáltatások rendszerét érintő kérdések, az oktatási módszerek és az információs technológiák nyújtotta lehetőségek kihasználásai.

A Mesabi Főiskola egyik kiadványa a sérült hallgatók esélyegyenlőségének biztosítására létrehozott segítő szolgálat munkáját mutatja be. A különböző szolgáltatások közül néhány meggyőző példa: az írásbeli vizsga formátumának módosítása; jeltolmács biztosítása; jegyzetelő készülékek (hordozható számítógépek) kölcsönzése; tananyag elöállítás (nagyított formátum, hangkazettán tárolt és digitalizált), speciális számítástechnikai eszközök és programok; tárgyfelvételnél előny biztosítása a sérült hallgatóknak (Turchi, 1994). McBroom 102 látássérült diák helyzetét mérte fel 66 egyetemen. Az elemzésből kiderül, hogy többségük rendelkezik olyan diáksegítő programmal, amely a látássérült hallgatók igényeihez alkalmazkodó, speciális szolgáltatást nyújt, melyek biztosítják a hallgató tájékozódását és tananyag- 
hoz való hozzáférését (McBroom, 1997). Két publikáció is foglalkozik olyan oktatási módszerekkel, melyekkel a sérült diákok sikeres előmenetele biztosítható felsőfokú tanulmányaik végzésében (Waksler, 1996; Hodge és Preston-Sabin, 1997).

Cain és Merill (2001) a legújabb technológiák és alternatív módszerek alkalmazását mutatja be hét, távoktatási egyetemi programban részt vevő látássérült hallgató vizsgálatával. A szerzők a hallgatók által használt információs technológiákat, az igényelt segítség formáját, az általuk preferált módszereket és a tanulási attitüdjeiket elemzi. Megállapítja, hogy a távoktatás olyan rugalmas tanulási technikákat és módszereket tesz lehetővé, amelyek a látássérült fiatalok speciális igényeit messzemenően kielégítik, ezért körükben igen népszerüek.

A hazai szakirodalomban elsőként Csányi Yvonne (1999) közölt cikket a sérült hallgatók felsőoktatási integrációjának problematikájáról. Olyan külföldi gyakorlatokat mutatott be, amelyek sokkal rugalmasabban kezelik a tantárgyak és a tanulmányi idő megválasztását. Szakirodalmi adatokra hivatkozva a sérült hallgatók arányát az európai és észak-amerikai felsőoktatási intézményekben 0,4 és 4 százalék közé helyezte, s akik között leggyakoribbak a mozgás- és a látássérültek. Csányi Yvonne 2001-ben a Magyar Felsőoktatás címü szaklapban megjelent publikációja már a fogyatékosügyi koordinátorok legföbb feladatait ismerteti. Ugyanebben az évben jelent meg az Eötvös Loránd Tudományegyetem Bárczi Gusztáv Gyógypedagógiai Főiskolai Karának útmutatója, a „Fogyatékos hallgatók a felsőoktatásban” címmel (Csányi, 2001). Ez a kiadvány az első hazai útmutató, mely az ország egyetemei és főiskolái számára kíván eligazítást, ismereteket és tanácsokat adni a sérült hallgatók sikeres integrációjának és esélyegyenlőségének biztosítására. A kiadvány ismerteti a hatályos törvényeket, az inklúziós szemléletet, a koordinátor lehetséges feladatait és a mozgás-, hallás- és látássérült hallgatók speciális igényeit, szükségleteit.

A fogyatékos hallgatók helyzete a magyar felsőoktatásban címü kutatás (2002) a magyarországi felsőoktatási intézmények 45,4 százalékának adatait elemzi. Megállapítja, hogy az összes sérült hallgató összhallgatói létszámhoz viszonyított aránya 0,17 százalék volt.

2002-ben jelent meg hazánkban az első olyan jogszabály, amely a fogyatékos hallgatók tanulmányaihoz szükséges esélyegyenlőséget biztosító feltételekről rendelkezik (29/2002. OM rendelet). E rendelet hatására egyre több hazai felsőoktatási intézmény kezdett komolyabban foglalkozni a fogyatékos hallgatókkal, intézményi fogyatékosügyi koordinátorok kinevezésével megpróbálták a rendelet elöírásai szerint megszervezni és biztosítani a különböző szolgáltatásokat. Három évvel a rendelet megszületése után végzett kutatást a fogyatékos hallgatók helyzetéről a Kurt Lewin Alapítvány (Héra, Kun és Ligeti, 2005). A tanulmányban megállapítják a szerzők, hogy a fogyatékos hallgatók alulreprezentáltak létszámukat és önérvényesítésüket tekintve egyaránt; hogy a fizikai akadálymentességet még csak néhány egyetem oldotta meg; hogy a koordinátori rendszer több sebből vérzik: a koordinátorok kijelölése szakmailag megalapozatlan; a munkában nem támaszkodhatnak szakmai segítségre; nem 
kapnak önálló státuszt és nincs szakirányú képzési lehetőség a számukra. A fogyatékos hallgatók legnagyobb problémája az információhiány.

A 2005-ös felsőoktatási törvény és az ennek végrehajtásáról szóló 2006-os kormányrendelet fogyatékos hallgatókra vonatkozó paragrafusai már átvezetnek minket a jelen helyzet taglalásába.

\section{A fogyatékos hallgatók aránya a felsőoktatásban}

Azt tapasztaljuk, hogy a hazai felsőoktatásban az utóbbi években nagymértékben megemelkedett a fogyatékos hallgatók száma, nyolc év alatt majdnem tízszeresére növekedett. (Lásd 1. ábra!)

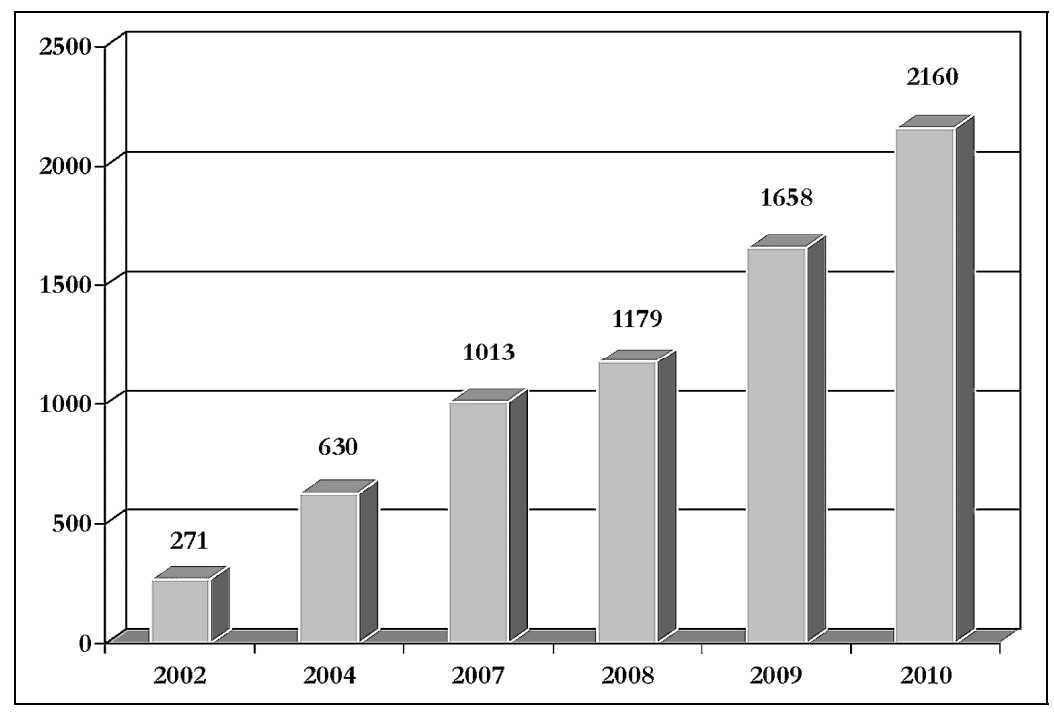

1. ábra: Fogyatékos hallgatói létszámok a 2002-2010 közötti időszakban Magyarország felsőoktatási intézményeiben (Forrás: NEFMI-től kapott nem publikált adatok)

Ugyanez a tendencia tapasztalható az egyetemek előszobáinak számító gimnáziumokban is, még akkor is, ha a középfokú oktatási intézmények közül legkevesebb diákot a gimnáziumok integrálnak. „Viszont az utóbbi öt évben itt volt a legnagyobb arányú a sajátos nevelési igényü tanulók létszámának növekedése. A 2007/2008-as tanévben 1025 diák tanult integráltan a gimnáziumokban, amely a teljes gimnáziumi tanulói létszám 0,4 százaléka, azaz 250 tanulónként egyetlen sajátos nevelési igényü. S még így is, az utóbbi öt évben ötszörösére növekedett az integrált tanulók száma a gimnáziumokban. A különböző gimnáziumtípusok között némi különbség tapasztalható az integrált tanulók arányában, így legkevesebben a nyolcosztályos gim- 
náziumokba jutnak be, kicsit többen a hatosztályosokba, s ettől még többen a négyosztályos évfolyamokra." (Kereki, 2010)².

Ha összehasonlítjuk a középiskolákban és az egyetemeken integráltan tanuló fogyatékos fiatalok 2007/2008-as létszámadatait - a középiskolákban 1025, míg az egyetemeken a 2007-es és 2008-as év átlagát tekintve 1096 diák - akkor megállapíthatjuk, hogy csak kismértékủ az eltérés, 71 fövel többen tanultak az egyetemeken az adott évben. Ha a számokat százalékos megoszlásra váltjuk, akkor azt tapasztaljuk, hogy míg a középiskolában tanuló sajátos nevelési igényü tanulók az adott évben 0,4 százalékos arányban vannak jelen, addig az egyetemek összhallgatói létszámához viszonyítva a fogyatékos hallgatók részvétele 0,27 százalékos arányt képvisel.

A 2010-es adatokat tekintve a felsőoktatásban tanuló fogyatékossággal élő hallgatók száma már 2160, ami az akkori 361000 -es hallgatói létszámnak 0,6 százaléka. A fogyatékos hallgatók jelenléte a felsőoktatási intézményekben tehát mind létszámukat, mind részvételi arányukat tekintve is megduplázódott, miközben az egyetemeken 2006-tól kezdődően fokozatos létszámcsökkenés volt tapasztalható. Vajon ez a 0,6 százalékos arány milyen nagyságrendet képvisel nemzetközi összehasonlításban? Néhány tengeren túli és európai ország adatait tartalmazza az 1. táblázat.

1. táblázat: Fogyatékos hallgatók aránya néhány országban

\begin{tabular}{|l|c|c|l|}
\hline \multicolumn{1}{|c|}{ Ország } & $\begin{array}{c}\text { Fogyatékos } \\
\text { hallgatók } \\
\text { aránya }\end{array}$ & $\begin{array}{c}\text { Adatszolgál- } \\
\text { tatás éve }\end{array}$ & \multicolumn{1}{|c|}{ Forrás } \\
\hline $\begin{array}{l}\text { Amerikai } \\
\text { Egyesült Államok }\end{array}$ & $11 \%$ & 2009 & $\begin{array}{l}\text { National Center for Education } \\
\text { Statistics. 2009 }\end{array}$ \\
\hline Ausztrália & $4 \%$ & 2010 & Ryan, 2011 \\
\hline $\begin{array}{l}\text { Dél-Afrikai } \\
\text { Köztársaság }\end{array}$ & $0,5 \%$ & 2009 & Mayat, Amosun, 2011 \\
\hline $\begin{array}{l}\text { Egyesült } \\
\text { Királyság }\end{array}$ & $8 \%$ & $2006 / 2007$ & $\begin{array}{l}\text { Disabled Students and } \\
\text { Higher Education, 2009 }\end{array}$ \\
\hline Franciaország & $0,32 \%$ & 1999 & Ebershold, Evans, 2003 \\
\hline Írország & $3,3 \%$ & $2009 / 2010$ & $\begin{array}{l}\text { Survey on the Participation Rates of } \\
\text { Students with Disabilities in Higher } \\
\text { Education for the Academic Year } \\
\text { 2009/2010 }\end{array}$ \\
\hline Németország & $3 \%$ & 2000 & Falkendorff, 2003 \\
\hline Svájc & $0,6 \%$ & 2001 & Hollenweger, 2003 \\
\hline
\end{tabular}

\footnotetext{
${ }^{2}$ http://koloknet.hu/?416-sajtos-nevelsi-igny-tanulk-a-kzpiskolban
} 
A fogyatékos hallgatókról készített statisztikák igen heterogén képet mutatnak. A legtöbb fogyatékos hallgató az Amerikai Egyesült Államok és az Egyesült Királyság egyetemein tanul, míg a legkevesebb - meglepő módon - Franciaországban. Igaz, hogy az adatszolgáltatások idejében tíz év különbséget találunk, a több mint harmincszoros különbség akkor is szembetünő. A tényekhez tartozik az is, hogy az 1990-es évekből származó publikációk is 9-10 százalékos részvételi arányról számoltak be az USA-ban (Henderson, 1992). Ha a magyar 0,6 százalékos részvételi arányt összehasonlítjuk a táblázatban szereplő nyolc ország adataival, akkor azt láthatjuk, nem feledve az időbeli eltéréseket, hogy az alsó harmadban foglalunk helyet Franciaországgal, Svájccal és a Dél-Afrikai Köztársasággal együtt. A középmezőnybe tartozik 3-4 százalékos fogyatékos hallgatói aránnyal Németország, Írország és Ausztrália.

\section{Fogyatékossági típusok}

Érdekes átalakulásnak lehetünk tanúi, ha a fogyatékos hallgatók összetételét tanulmányozzuk nemzetközi szinten. Az Amerikai Egyesült Államokban a nyolcvanas években a fogyatékos hallgatók között legtöbben látássérültek, vagy mozgáskorlátozottak voltak (Henderson, 1999). 2008-ra az első évfolyamos fogyatékos hallgatók között már 3,3 százalékot tett ki a különböző tanulási zavarok (diszlexia, diszgráfia, diszkalkulia, hiperaktivitás és figyelemzavar) aránya, miközben ez az arány 1983-ban csak 0,05 százalék volt (Pryor et al., 2008). 2001-re már az összes amerikai egyesült államokbeli felsőoktatási intézményben a fogyatékosként regisztrált hallgatók több mint fele tanulási zavarral küzdött (Hallahan és Mercer, 2001). 2010-re az arány az összes hallgatóra vetítve 9 százalékra nőtt, ami a fogyatékos hallgatóknak 80 százalékát teszi ki (Cawthon és Call, 2010). Ez a kiugróan magas szám azt jelenti, hogy az elmúlt közel 30 év alatt az USA-ban a felsőoktatásban tanuló hallgatók sérülés szerinti összetétele teljesen megváltozott, a tanulási zavarral küzdő hallgatók aránya pár százalékról nyolcvan százalékra nőtt.

Svájcban a felsőoktatási intézményekben tanuló fogyatékos hallgatók között Hollenweger (2003) 45 százalék érzékszervi: látás-, vagy hallássérülést, 41 százalék mozgáskorlátozottságot, 9 százalék tanulási zavart, 4,5 százalék halmozott sérülést és 0,5 százaléknál ismeretlen eredetet talált. A pszichés eredetủ fogyatékosságok és a krónikus betegségek nem szerepeltek a felmérésben.

Németországban a fogyatékossággal élő hallgatók 70 százaléka érzékszervi, mozgás-, vagy beszédfogyatékos, 30 százaléka diszlexiás. Külön kategóriát jelent a regisztrálásnál a krónikus betegség, ami az összhallgatói létszám 13 százalékát teszi ki (Falkendorff, 2003).

Az Egyesült Királyságban a 2009-es DIUS kutatás megállapította, hogy a fogyatékos hallgatók 50 százaléka diszlexiás, 15 százalékának krónikus betegsége, 10 százalékának ún. más vagy egyéb fogyatékossága, 8 százalékának halmozott sérülése, 
5 százalékának pszichés vagy pszichiátriai sérülése, 4 százalékának hallássérülése, 4 százalékának mozgássérülése, 3 százalékának látássérülése és 1 százalékának autizmus-spektrum zavara van (Disabled..., DIUS Research Report, 2009, 21. o.).

A fogyatékos hallgatók sérülési típus szerinti megoszlására friss hazai adatot nem találtam. A fogyatékos hallgatók helyzete a magyar felsőoktatásban címü, már említett kutatás (2002) a magyarországi felsőoktatási intézmények 45,4 százalékának adatait elemzi. Megállapítja, hogy ezen intézmények 56 százalékában képeznek fogyatékos hallgatókat is. Legnagyobb arányban mozgássérült (69 fö) és látássérült hallgatókat (59 fö) találtak. A hallássérült hallgatók száma a vizsgált intézményekben 20 fó volt. Mivel a sérülési típusokra vonatkozó országos érvényü statisztikai adat nem állt rendelkezésemre, az Eötvös Loránd Tudományegyetem adatait elemezem. Az egyetemen évröl évre nő a fogyatékossággal élő regisztrált hallgatók létszáma. Az ELTE fogyatékosügyi koordinátora által regisztrált adatok alapján a 2007/2008-as tanévben 128, míg a 2010/2011-es tanévben 293 fogyatékos hallgató tanult az egyetemen, ami három év alatt több mint kétszeres létszámemelkedést jelentett (lásd 2. táblázat).

2. táblázat: A hallgatók fogyatékosság szerinti összetétele (ELTE)

\begin{tabular}{|c|c|c|c|c|c|c|c|c|}
\hline \multicolumn{9}{|c|}{ Fogyatékos hallgatói létszámadatok 2010/2011. tanév } \\
\hline Kar & 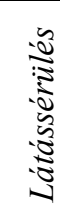 & 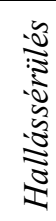 & 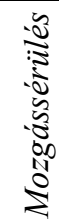 & 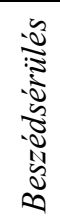 & $\begin{array}{l}0 \\
5 \\
0 \\
0 \\
0 \\
0 \\
0 \\
0\end{array}$ & 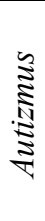 & 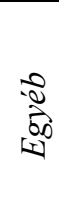 & $\begin{array}{l}\tilde{N}^{2} \\
: 0^{2}\end{array}$ \\
\hline TTK & 2 & 5 & 11 & 6 & 30 & 2 & - & 56 \\
\hline BTK & 17 & 6 & 30 & 3 & 31 & 1 & 3 & 91 \\
\hline IK & 3 & 3 & 4 & - & 14 & 3 & 1 & 28 \\
\hline ÁJK & 4 & 1 & 5 & - & 2 & 1 & - & 13 \\
\hline TÁTK & 4 & 3 & 8 & 3 & 11 & - & - & 29 \\
\hline BGGYK & 7 & 4 & 7 & - & 8 & - & 1 & 27 \\
\hline PPK & 13 & 8 & 5 & 1 & 16 & - & 5 & 48 \\
\hline TÓK & - & - & - & - & 1 & - & - & 1 \\
\hline ÖSSZES & 50 & 30 & 70 & 13 & 113 & 7 & 10 & 293 \\
\hline
\end{tabular}

Forrás: az ELTE fogyatékosügyi koordinátorának adatgyüjtése

A hallgatók 38 százaléka tanulási zavarral küzd, ez a sérülési típus fordul elő legnagyobb számban az ELTE-n. A második legnépesebb fogyatékossági csoport a mozgáskorlátozott hallgatók köre, akik 24 százalékát adják az egyetemen tanuló fogyaté- 
kos hallgatóknak. A látássérült diákok aránya az ELTE-n 17, a hallássérült hallgatóké pedig 10 százalék. A beszédsérülés és az autizmus (összesen 0,6\%) nagyon alacsony számban található az ELTE-n.

\section{Eltérő definíciók}

Hazánkban a fogyatékossági típusok megnevezésében és definíciójában a különböző jogszabályok tekintetében eltérés tapasztalható (pl. a közoktatásban érvényes jogszabályok hallássérült, látássérült tanulóról, míg a fogyatékosság minősítésének jogszabályai hallási fogyatékos, vagy látási fogyatékos személyről rendelkeznek).

Nem célom e különbségek sokoldalú elemzése, csupán egyetlen szempontot tartok e tanulmány kereteiben vizsgálhatónak: a fogyatékosság eltérő értelmezéseit a különböző országok felsőoktatási gyakorlatában.

Magyarországon a 2005. évi CXXXIX. és a 2011. évi CCIV felsőoktatási törvények szerint „fogyatékossággal élő hallgató (jelentkezö): aki testi, érzékszervi, beszédfogyatékos, autista, megismerés és viselkedés fejlődési rendellenességü". A 79/2006. (IV. 5.) Kormányrendelet 18. §-a az alábbi csoportosításban definiálja a fogyatékos hallgatókat és az előnyben részesítés követelményeit: mozgáskorlátozott, hallássérült (siket, nagyothalló), látássérült (vak, gyengénlátó), beszéd- és más fogyatékos (különösen súlyos beszédhiba, diszlexia, diszgráfia, diszkalkulia), valamint autista. Érdekes módon a kormányrendelet nem tesz említést a törvényben szereplő megismerés és viselkedés fejlődési rendellenességü hallgatókról. Sem e törvény, sem a kormányrendelet nem határozza meg pontosan a különbözö fogyatékossági kategóriákat, a fogyatékosság megítélését részben a szakértői és rehabilitációs bizottságokra (amennyiben a fogyatékosság a közoktatásban eltöltött idő alatt keletkezett), részben a Nemzeti Rehabilitációs és Szociális Hivatalra bízza. A 2011-es törvény végrehajtásáról szóló rendelet még nem készült el, így annak változásairól nincs tudomásom. A fogyatékosság megítélésével kapcsolatban van egy igen szembetünő ellentmondás, melyet a látássérülés meghatározásán keresztül szemléltetek. Kétféle definíció érvényes a látássérülés megállapítására a 18. életévüket betöltött személyek esetén. Ha a tanuló a középiskola végzésének időszakában, vagy előtte válik látássérültté (az érettségi bizonyítvány megszerzéséig), akkor a 2/2005. (III. 1.) OM rendelet 2. számú mellékletében foglalt definíció érvényes rá: „, $A$ gyógypedagógiai nevelés, oktatás szempontjából azok a tanulók látássérültek, akiknek látásteljesitménye (vízusa) az ép látáshoz (vizus: 1) viszonyitva két szemmel és korrigáltan (szemüveggel) is 0-0,33 (látásteljesitmény 0-33 \%) közötti.." E rendelet alapján adja ki a szakvéleményt a Látásvizsgáló Országos Szakértői és Rehabilitációs Bizottság. Ha a tanuló az érettségi bizonyítvány megszerzése után, vagyis a közoktatási rendszert elhagyva veszíti el látását, akkor a 21/2003. (II. 25.) A súlyos fogyatékosság minősítésének és felülvizsgálatának, valamint a fogyatékossági támogatás folyósításának szabályairól szóló Kormány rendelet érvényes rá: „Látási fogyaté- 
kosnak azt a személyt kell tekinteni a) akinek látóélessége megfelelö korrekcióval aa) mindkét szemén 5/70 (0,07), ab) az egyik szemén 5/50 (0,1), a másik szemén három méterröl olvas ujjakat (0,03),ac) az egyik szemén 5/40 (0,125), a másik szemén fényérzékelés nincs, vagy a másik szeme hiányzik; rövidlátás esetén - a fenti látásélesség értékeitöl függetlenül - csak az jogosult a fogyatékossági támogatásra, akinek közeli látásélessége Csapody V., vagy annál rosszabb, vagy b) akinek látótere mindkét oldalon körkörösen húsz foknál szükebb."

A terminológia használatában különbség van a közoktatásban vagy a felsőoktatásban résztvevők megnevezésére: 18 év alatt látássérült, afölött látási fogyatékos. A vízus alapú meghatározásban 18 év alatt látássérült, ha a látásélessége $0-0,3,18$ év felett pedig két szemmel maximum 0,07, egy szemmel maximum 0,125. A látássérülést abban is eltérően értelmezi a két rendelet, hogy mely látási funkciókat veszi számításba (a közoktatásban alkalmazandó meghatározásban például nem szerepel a látótérszükület).

A megismerés és viselkedés fejlődési rendellenesség meghatározása is ellentmondásos: az Educatio Társadalmi Szolgáltató Nonprofit Kft. hivatalos állásfoglalása szerint: „A kategória meghatározása - elsősorban a tudományterületi átfedések miatt - a szakirodalomban sem egységes. A teljesség igénye nélkül néhány fontosabb és ismertebb részterület kiemelhető: olvasási zavarok (diszlexia), írási zavarok (diszgráfia), helyesírási zavarok (diszortográfia), számolási zavarok (diszkalkulia), viselkedési zavarok (pl. hiperaktivitás, figyelemzavarok stb.)." ${ }^{3}$ Ez azt jelenti, hogy a diszlexiát, diszgráfiát és diszkalkuliát, melyeket a 79/2006. (IV. 5.) Kormányrendelet a beszéd- és más fogyatékosságok körébe tartozónak ítél, az Educatio Kft a megismerési és viselkedési fejlődési rendellenességek kategóriájába sorolja. Ennek alapja az 1993-as LXXIX. Közoktatási Törvény $121 . \S$-a, amely megkülönböztet ún. SNI A és SNI B tanulókat (SNI = sajátos nevelési igény) és mindkettőt a megismerő funkciók vagy a viselkedés fejlődésének tartós és súlyos rendellenességei cím alá helyezi. Megállapítható tehát, hogy a különböző oktatási szinteket, valamint a szociális támogatást szabályozó törvények és rendeletek fogyatékosságot érintő rendelkezéseinek terén nem történt meg a jogharmonizáció.

A hazai felsőoktatási gyakorlatban a legnagyobb hiányosság a fogyatékosság szük értelmezése annak ellenére, hogy hazánk 2007-ben ratifikálta a Fogyatékossággal élő személyek jogairól szóló ENSZ Egyezményt. Az Egyezmény szerint „Fogyatékossággal élő személy minden olyan személy, aki hosszan tartó fizikai, értelmi, szellemi vagy érzékszervi károsodással él, amely számos egyéb akadállyal együtt korlátozhatja az adott személy teljes, hatékony és másokkal egyenlő társadalmi szerepvállalását."

\footnotetext{
${ }^{3} \mathrm{http}: / / \mathrm{www}$. felvi.hu/felveteli/pontszamitas/Alapkepzesben/fogyatekossaggalelok

${ }^{4}$ http://www.szmm.gov.hu/main.php?folderID=16485
} 
A „szellemi károsodás” kifejezés az eredeti angol szövegben „mental impairments", ami a pszichés, vagy pszichiátriai betegségeket jelenti. Ezt azért tartom fontosnak, mivel a hazai felsőoktatásban alkalmazott fogyatékosság terminológia nem tartalmazza a pszichés zavarokat, következésképpen az ENSZ Egyezmény szerint fogyatékossággal élő hallgatók számottevő csoportját a mai magyar felsőoktatás hivatalosan nem részesíti előnyben. Ugyanez a helyzet egyéb tartós betegségek esetén is, a felsőoktatási intézményeket semmilyen jogszabály nem kötelezi a különböző krónikus betegséggel küzdő hallgatók megsegítésére.

A legtöbb európai országban, csakúgy, mint az USA-ban a fogyatékosság tág értelmezése jelenik meg a felsőoktatásban, ami tehát tartalmazza a klasszikus fogyatékossági típusokat, az ún. pszichoszociális fogyatékosságokat és a krónikus betegségeket is.

\section{A fogyatékos hallgatóknak nyújtott szolgáltatások}

A fogyatékossággal élő hallgatóknak nyújtott szolgáltatások igen sokfélék lehetnek, kezdve a könnyebben megszervezhető tanácsadástól a sokkal szofisztikáltabb valós idejü feliratozásig. Ez a szolgáltatás a hallássérült vagy siket hallgatóknak jelent segítséget abban, hogy az előadást megértsék: a tanár előadását egy speciálisan kiképzett gépíró lejegyzi, amelyet a hallgató a kivetítőn a tanár beszédével közel azonos időben elolvashat.

Az európai országok többségében (például: Egyesült Királyság, Benelux államok, Németország, Spanyolország) és az USA-ban a fogyatékos hallgatók megsegítését egy erre a feladatra kijelölt munkacsoport végzi, amely gyógypedagógusokból, pszichológusokból, pedagógusokból és szociális munkásokból áll. A speciális szolgáltatásokat általában fogyatékos hallgatói központok nyújtják vagy szolgáltatások címen lehet megtalálni az egyetemek honlapjain. Ezek a központok sokrétü munkát végeznek, vezetőjük általában az intézményi fogyatékosügyi koordinátor. Feladatuk a hallgatók toborzása és regisztrálása, a fogyatékos hallgatók egyéni igényeinek felmérése és ezek kielégítése, vagyis a segítség megszervezése és nyújtása (Falkendorff, 2003). A fogyatékos hallgatók segítő központjai tehát bizonyos esetekben konkrét segítséget adnak a hallgatóknak, például vak hallgatóknak digitalizálják a tananyagot, vagy a tanulási zavarban szenvedő hallgatóknak tanulás-módszertani képzést és plusz órákat biztosítanak (Janiga és Costenbader, 2002). Más esetekben megszervezik a segítségnyújtást gyakran az egyetem belső forrásainak felhasználásával: személyi segítőket, jegyzetelést végző hallgatókat toboroznak, külső szolgáltatásokat rendelnek meg a hallgató igényének kielégítésére, például jeltolmácsok biztosítása siket hallgatóknak, vagy útvonaltanítás vak hallgatóknak, Tágabb értelemben a fogyatékos hallgatókat segítö központok feladata a felsőoktatási intézmény fogyatékosügyi politikájának képviselete és népszerüsítése, a széleskörü tájékoztatás (szülők, középiskolások, fogyatékosügyi szervezetek stb.), a fo- 
gyatékos személyek érdekvédelmi szervezeteivel, rehabilitációs intézményeivel és a támogató szolgálataival történő kapcsolattartás és az oktatók fogyatékosüggyel kapcsolatos képzése.

A fogyatékossággal élö hallgatóknak nyújtott szolgáltatások típusa részben az adott ország szociális támogatási rendszereitől, részben a felsőoktatás finanszírozásától függ. Azokban az országokban, amelyekben a hallgató a fogyatékossága miatt saját jogon részesül emelt támogatásban, az intézménynek nem kell az önálló tanulást segítő speciális eszközparkra költenie, hiszen ezeket a hallgató meg tudja vásárolni. Ez a helyzet például Hollandiában, az Egyesült Királyságban, vagy Németországban. Ezt a támogatást , hátizsák” elvnek nevezik, ami annyit jelent, hogy ha a hallgató intézményt vált, viszi magával a saját speciális eszközeit az új intézménybe.

Magyarországon a helyzet sok mindenben eltér a fentebb említett országokétól. Nálunk a felsőoktatási intézmények többségében nincs fogyatékos hallgatókat segítő központ. A kivételek közé tartozik a Pécsi Tudományegyetem és a Debreceni Egyetem, ahol támogató szolgálat segíti a fogyatékos hallgatókat, vagy a Szegedi Tudományegyetem, ahol az életvezetési tanácsadó központ látja el e feladatokat. Az ország egyik legnagyobb egyetemén, az Eötvös Loránd Tudományegyetemen nincs fogyatékos hallgatókat segítő központ, de a kari koordinátorok és a Kortárs Segítő Csoport aktív munkája révén többféle szolgáltatást is nyújt az egyetem. Ezek közül néhány: eszközkölcsönzés a hallgatóknak; speciális módszerekkel történő idegen nyelvi képzés; tanulási és életvezetési tanácsadás; személyi segitők biztosítása; hallgatók kísérése; tananyag adaptálás: digitalizálás, fénymásolás, nyomtatás; oktatók és hallgatók képzése érzékenyítő programokkal.

A hazai egyetemek, föiskolák fizikai akadálymentesség tekintetében nagyon nagymértékben elmaradnak a nyugat-európai és amerikai felsőoktatási intézményektől. Az egyetemes tervezés gyökere Európában (elsősorban a skandináv országokban) az 1960-as, az USA-ban az 1970-es évekre nyúlik vissza. „Az egyetemes tervezés eszméje az a preventív gondolkodásmód, tervezési stratégia, amely már a tervezés folyamatának az elején figyelembe veszi a használók képességeinek különbözőségét. E tervezési stratégia gyakorlásával olyan termékek jönnek létre, amelyek különleges tervezési megoldások és adaptáció nélkül biztosítják a lehető legtöbb ember számára a legteljesebb és legönállóbb használhatóságot. Jelen esetben a „termékek” megnevezés a legkülönbözőbb használati tárgyakon, eszközökön túl valamennyi, az ember által formált környezetre, szolgáltatásra és infrastruktúrára is vonatkozik, tehát a köz-, és lakóépületekre is." (Pandula, 2007, 11. o.) Mivel hazánkban a felsőoktatási intézmények sok esetben régebbi építésü épületekben helyezkednek el, az egyetemes tervezés eszméjének megfelelő átépítésükhöz nagyobb anyagi forrásra van szükség. A szemléletváltást tükrözi, hogy az újabb építésü egyetemi, főiskolai épületek már az akadálymentesség jegyében születnek meg, de a teljes körü hozzáférést még ezek sem biztosítják, vagyis nem alkalmazzák az egyetemes tervezés filozófiáját - például a mozgáskorlátozott személyek számára az épület hoz- 
záférhető, de a látássérült emberek számára semmilyen tájékozódást segítő elem tervezése és építése nem valósul meg.

Összegzésként elmondható, hogy hazánk felsőoktatási intézményei a fogyatékossággal élő hallgatóknak nyújtott szolgáltatások és a fizikai, valamint infokommunikációs hozzáférés terén nem éri el az Európai Unió fejlettebb országainak szintjét. Ugyanakkor pozitív szemléletet tükröz, hogy a fogyatékossággal élö hallgatók jogait a felsőoktatási törvény szabályozza, számukra előnyben részesítést ír elő. A jövőben nagyobb hangsúlyt kell kapnia a fogyatékos hallgatóknak nyújtott szolgáltatások minőségfejlesztésének, amely olyan multidiszciplináris teamek alkalmazását teszi szükségessé, akik egy fogyatékos hallgatók segítésére létrehozott központ keretein belül magas szintű szakmai tudással, pozitív attitüddel, közvetlen szolgáltatásokkal biztosítják a fogyatékos hallgatók egyenlő esélyü részvételét a felsőoktatásban. A növekvő hallgatói létszám egyre sürgetőbbé teszi e központok létrehozását.

\section{Irodalom}

A fogyatékos hallgatók helyzete a magyar felsőoktatásban. Kutatási zárójelentés (2002). Oktatási Minisztérium és Ifjúsági és Sport Minisztérium, Budapest, 10-16.

A Fogyatékos Személyek Jogairól szóló ENSZ Egyezmény 2006. Letöltés ideje: 2012. 04. 17. http://www.szmm.gov.hu/main.php?folderID=16485

Bennett, R. E. et al. (1984): GRE score level, test completion and reliability for visually impaired, physically handicapped, and nonhandicapped groups. Journal of Special Education, No. 3. 9-21.

Cain, H. M., Merill, Z. (2001): Distance education for Master's students with visual impairments: technology and support. Journal of Visual Impairment and Blindness, No. 9. $572-575$.

Cawthon, S. W., Cole, E. (2010): Postsecondary Students who have a Learning Disability: Student Perspectives on Accommodations Access and Obstacles. Journal of Postsecondary Education and Disability, No. 2. 118-141.

Csányi Yvonne (1999): Fogyatékosok a felsőoktatásban. Magyar Felsőoktatás, 8. sz. 17-19.

Csányi Yvonne (2001): A fogyatékossággal élő hallgatók a felsőoktatásban. Magyar Felsőoktatás, 5-6. sz. 30-31.

Csányi Yvonne (szerk., 2001): Fogyatékos hallgatók a felsőoktatásban. Útmutató. ELTE BGGYFK, Budapest.

Disabled Students and Higher Education. Higher Education Analysis. DIUS Research Report, 2009. Department for Innovation, Universities and Skills. Crown Copyright 2009. Letöltés ideje: 2012. 04. 10.

http://www.bis.gov.uk/assets/biscore/corporate/migratedd/publications/d/dius_rr_09_06.pdf

Ebershold, S., Evans, P. (2003): Access to Higher Education: its Dynamics, Shortcomings and Obstacles. In: Disability in Higher Education. OECD, Paris, 15-31.

Ebershold, S., Evans, P. (2003): Students with Disabilities in the United Kingdom. In: Disability in Higher Education. OECD, Paris, 81-104. 
Falkendorff, K. (2003): Disability and Higher Education in Germany. In: Disability in Higher Education. OECD, Paris, 109-146.

Fogyatékossággal élők többletpontjai. Letöltés ideje: 2012. 04. 16. http://www.felvi.hu/felveteli/pontszamitas/Alapkepzesben/fogyatekossaggal_elok_tob bletpontjai

Finger, A. (2006): Randolph Bourne. In: Gary, L. A. (ed.): Encyclopedia of Disability. Vol. 1. Sage Publications Inc. Thousand Oaks, Calif.

Hallahan, D. P., Mercer, C. D. (2001): „Learning Disabilities: Historical Perspectives.” White Paper from the Learning Disabilities Summit. Washington, D.C. Letöltés ideje: 2012.04. 08.

http://elearndesign.org/teachspecialed/modules/ocada7021_norm2/15/xmedia/Kenneth_ A_Kavale.pdf

Henderson, C. (1999): College Freshmen with Disabilities: A Biennial Statistic Profile. Statistical Year 1998. American Council on Education, HEATH Resource Center. Washington, DC. Letöltés ideje: 2012. 04. 19.

https://portfolio.du.edu/portfolio/getportfoliofile?uid=83677

Héra Gábor, Kun Eszter, Ligeti György (2005): Fogyatékossággal élők a felsőoktatásban. Kutatási beszámoló. Készült: az Oktatási Jogok Biztosának Hivatala megbízásából. Kurt Lewin Alapítvány a toleranciáért, Budapest. Letöltés ideje: 2012. 04. 12. http://kla.hu/uploads/media/kut_fofe.pdf

Hodge, B. M., Preston-Sabin, J. (ed., 1997): Accomodations - or just good teaching? Strategies for teaching college students with disabilities. Greenwood Publishing, Westport, CT.

Hollenweger, J. (2003): Students with Disabilities in Higher Education in Switzerland. In: Disability in Higher Education. OECD, Paris, 149-166.

Janiga, S. J., Costenbader, V. (2002): The Transition From High School to Postsecondary Education for Students with Learning Disabilities: A Survey of College Service Coordinators. Journal of Learning Disabilities, Sept./Oct., 463-470.

Kereki Judit (2010): Sajátos nevelési igényü tanulók a középiskolában. Letöltés ideje: 2012. 04. 06. http://koloknet.hu/?416-sajtos-nevelsi-igny-tanulk-a-kzpiskolban

Kleege, G. (2006): Helen Keller. In: Gary, L. A. (ed.): Encyclopedia of Disability. Vol. 3. Sage Publications Inc., Thousand Oaks, Calif., 1011.

Lawrence, J. et al. (1981): The handicapped student in America's colleges: a longitudinal analysis. Part 3: Disabled 1978 College Freshmen three years later. Higher Education Research Inst., Inc., Los Angeles, Calif. [82].

Leon, J. (2006): Ed Roberts. In: Gary, L. A. (ed.): Encyclopedia of Disability. Vol. 3. Sage Publications Inc, Thousand Oaks, Calif., 1417.

Madaus, J. (2011): The History of Disability Services in Higher Education. New Directions for Higher Education, No. 154, 5-6.

Mayat, N., Amosun, S. L. (2011): Perceptions of Academic Staff towards Accommodating Students with Disabilities in a Civil Engineering Undergraduate Program in a University in South Africa. Journal of Postsecondary Education and Disability, No. 1. 53-59. 
McBroom, L. W. (1997): Making the grade: college students with visual impairments. Journal of Visual Impairment and Blindness, No. 3. 261-270.

National Center for Education Statistics. 2009. Digest of Education Statistics. Accessed July 20, 2010. Letöltés ideje: 2012. 04. 17. http://nces.ed.gov/programs/digest/d09/tables/dt09_231.asp

Pandula András (szerk., 2007): Tervezési segédlet az akadálymentes épitett környezet megvalósitásához. ÖTM Területfejlesztési és Építésügyi Szakállamtitkárság, Budapest.

Perlman, R. (2008): The Blind Doctor: the Jacob Bolotin Story. Braille Monitor, No. 1. Letöltés ideje: 2012 . 04. 20. http://nfb.org/images/nfb/publications/bm/bm08/bm0801/bm080105.htm

Pryor, J. H., et al. (2008): The American Freshman: National Norms for Fall 2008. Higher Education Research Institute, University of California. Los Angeles. Letöltés ideje: 2012.04. 16.

http://heri.ucla.edu/PDFs/pubs/TFS/Norms/Monographs/TheAmericanFreshman2008.pdf

Ryan, J. (2011): Access and Participation in Higher Education of Students with Disabilities: Access to What? Australian Educational Researcher, No. 1. 73-93.

Servicemen's Readjustment Act 1944. Letöltés ideje: 2012. 04. 16. http://www.ourdocuments.gov/doc.php?flash=true \&doc $=76$

Stilwell, D. N., Stilwell, W. E., Perritt, L. C. (1983): Barriers in higher education for persons with handicaps: A follow-up. Journal of College Student Personnel, 24, 337-343.

Survey on the Participation Rates of Students with Disabilities in Higher Education for the Academic Year 2009/2010. AHEAD Educational Press 2010. 5.

Turchi, J. (1994): Students with Disabilities. A Resource Guide for Mesabi Communit, College, 7-58.

Waksler, R. (1996): Teaching strategies for a barrier-free classroom. Journal on Excellence in College Teaching, No. 2. 99-111.

Wilkinson, R. (ed.) (1981): Everything you wanted to know about handicapeed students (and were not afraid to ask). State University of New York, Office of Services for the Handicapped, Buffalo, NY., 2-17.

Willingham, W. W. (1987): Handicapped applicants to college: an analysis of admissions decisions. College Board Report, No. 87-1. New York, 1-24. 